\title{
Application of Ayurvedic Therapy in the Shakyamuni Dharma: A Literature Review
}

\author{
Dr. Vishnu G. Sonune, B. A. M.S., M.D. (Balrog), \\ Lecturer, ASPM Ayurvedic College, Buldana, Maharashtra, India
}

\begin{abstract}
Children in the modern age suffer at large due to physical problems; in addition to that they also suffer from psychological problem too. Often this is because their parents are too busy and cannot afford much time to look after them. As a result of that children lack love from their parents which make them unhappy. Although they are too young to express it, they hold the negative impression inside, which affect their personalities. The events leave a lasting impression on the tender mind of children and later become the cause of behavioural or psychosomatic diseases. Among these, Bedwetting is one of the obstinate problems. Due to this problem a lot of concealment and profound repercussions occur in family life, since a child's psychosomatic health and mothers pride involved with this problem. It affects small to middle age group of children mainly but adolescents are also found among sufferers, it affects all races and children from all geographical areas. Children are most among the sufferers of bedwetting may because of starting of development of personality and ego since the age of 3 years which culminates as negativism against parents when they force them to control the bladder. Kaumarabhritya emerged as an independent medical specialty right from the dawn of civilization. This revolutionary development was the result of increasing awareness among the health professionals that, the problems of children differ considerably from those of adults and from the point of view of medical therapeutics, "a child cannot be considered as miniature adult". Though paediatrics as a science has evolved much since then, this basic observation still remains valid.
\end{abstract}

Keywords: Shayyamutra, Bruhtrayee, enuresis

\section{Introduction}

Child health has assumed great significance in all over world. Enuresis or Shayyamutrais a repeated inability to control urination. The prevalence ofenuresis is about 15 $25 \%$ of children at 5 years of age, $8 \%$ of 12 years of age in male child and $4 \%$ of 12 years old female child. Boys suffer more often than girls because girls typically achieve each milestone before boys. Children can feel embarrassed and guilty about wetting the bed. Children may afraid to sleep over at friends home for fear of having enuresis. Parents often feel helpless to stop it. This problem can lead to long lasting effects on children psychological life. Currently it is believed that the condition is multifactorial. The cause of enuresis or Shayyamutrais genetic, physiological, functional and psychological. Very limited references about this disease are available in various Ayurvedic texts. There are many treatment option are nowavailable for the same. Ayurveda considers patientcounseling, diet control and Prakriti towards the disease control. Though the ancient texts explain almost about Shayyamutra, the available literatures fromvarious texts when put together, a hypothesis can begenerated which is as follows- the Basti loses urine holding capacity (Mutradharan Kshamata) during sleep and urine is passed out without the desire of micturition. A brief description regarding Shayyamutra is found in Sharangadhra Samhita. The process of urine formation is aided by Prana, Vyana and Apanavata and AvalambakaKapha with the overall control of mind. Micturition is one of the functions of normal ApanaVata. The activities of Apana are regulated by Prana and Vyanavata. The Apana facilitates active secretion of urine, motion, semen etc

After attaining a level of developmental maturity, there develops a control over these activities initiated by Prana and Vyana. But in this condition the overall control of activities of Apana is not developed resulting in vitiation of which in turn loss of control of micturition. The vitiation may also be due to encircling (Avarana) of Apana by Kapha which accelerates the excretion of urine. Brain plays an important role in both physiological as well as pathological process of body. It functions constantly even during sleep. According to Ayurveda, when it is mask by tama and Kapha, sleep is caused and delayed bladder maturation, worm infestation, in rare cases structural anatomical defect in external genetelia, Excessive sleep, Stress, anxiety, underlying fear and such other emotional problems may causes the Shayyamutra. This may happen in day time also, but in night, loss of control of Prana and Vyana over Apana and encircling of Apana by Kapha and tama happens together and the child unknowingly urine in the bed.

\section{Management of Shayyamutra according to Ayurveda:}

\section{1) SatvavajayaChikitsa}

It is an Ayurvedic therapy; in which the Sattva (mental status) of patient is improved.

\section{2) Counselling}

Counselling is a form of Satvavajaya Chikitsa. It forms the main basis for treatment. Both kids and the parent need assurance. Many kids think that they are the only one who wet the bed. This anxiety makes the problem worse. They feel guilty about it and continue to wet in the bed more and more. They need to be assured that it is quite common and natural and most of the kids do wet the bed. There is nothing bad about it. It is just a temporary problem. It will go away with medicine.

\section{Mechanism that prevents bed wetting}

Two physical functions prevent bedwetting. The first is a hormone that reduces urine production at night. The second is the ability to wake up when the bladder is full. Children usually achieve night time dryness by developing one or both of these abilities. There appear to be some hereditary factors in how and when these develop. The first ability is a 
hormone cycle that reduces the body's urine production. At about sunset each day, the body releases a minute burst of antidiuretic hormone (also known as arginine vasopressin or AVP). This hormone burst reduces the kidney's urine output well into the night so that the bladder does not get full until morning. This hormone cycle is not present at birth. Many children develop it between the ages of two and six years old, others between six and the end of puberty, and some not at all. The second ability that helps people stay dry is waking when the bladder is full. This ability develops in the same age range as the vasopressin hormone, but is separate from that hormone cycle. The typical development process begins with one- and two-year-old children developing larger bladders and beginning to sense bladder fullness. Two- and three-year-old children begin to stay dry during the day. Four- and five-year-olds develop an adult pattern of urinary control and begin to stay dry at night. Considering these mechanism, in allopathic medicine treatment options include anticholinergics, antispasmodic agents, and tricyclic antidepressants (TCAs). Applying above principles of treatment following drugs/ therapies can be used successfully in management of Shayyamutra in Ayurveda.

NasyaNasa i.e. Nose is considered to be the gateway to brain. Hence drug administered through nose may affect brain and hence the delayed neurological development may get corrected. Nasya also improves hormonal synthesis and endocrine function. Moreover Medhya drugs given by Nasya get absorbed easily crossing blood brain barrier through vascular pathway or diffusion of drugs.

Shirodhara Stress, inferiority complex and other psychological aspects of the disease may get covered with Shirodhara. Shirodhara is a purifying and rejuvenating therapy designed to eliminate toxins and mental exhaustion as well as relieve stress and any ill effects on the central nervous system regulates a wide variety of neuropsychological processes along withsleep. Shirodhara also have Alpha Adrenergic blocking effect and can thus block certain actions of adrenaline and nor adrenaline thus reducing stress.

Brahmi/ Shankhpushpi / Guduchi / Yashtimadhu. These four drugs have been given prime importance by Charaka as MedhyaRasayana. Brahmi possess neuroprotective properties, have nootropic activity beside it improves cognitive functions and social adaptability. Shankhapushpi possesses antidepressant effect. Yashtimadhu possesses anxiolytic and memory enhancing effect. Guduchi is having antistress and antioxidant properties. Hence these drugs either single or in combination can be used safely for long duration to overcome the delayed neurological development in Shayyamutra.

DhaturaDhatura is Madhura, Katu, Tikta, Kashaya (Rasa), Guru, Ruksha, Tikshna (Guna), Ushna (Virya), Katu (Vipaka) and Kapha-hara in nature. It is the drug having an anticholinergic, antispasmodic and antihistaminic effect. Hence it is considered to be effective in bed wetting.

\section{Conclusion}

Shayyamutrais common problem amongst children and great care along with treatment needto be taken to control disease consequences in early age counseling along with drug therapyproved to be more effective treatment. Also prescribe diet control and patient counseling as great tool for disease control. Various studies reveal that pharmacological treatment help patient more when associated with psychological treatment of Shayyamutra.

\section{References}

[1] Richard E, Behsnanh Robert M. klieg man Hal B J enson; Nelson textbook of pediatrics. Saunders Elsevier, A division of Reed Elsevier India private limited, New Delhi, 18th Ed, 2008; 72-73.

[2] American Academy of Pediatrics Practice Guideline; Diagnoses and Evaluation of child; Pediatrics, 105: 1158-2000.

[3] The ICD -10; classification of mental and behavioral disorders. Clinical description and diagnostic guideline. WHO Geneva 1992 http://www.who.int/iris/handle/10665/37958.

[4] Article by Dr. M S Krishnamurthy and Dr. Heber. easyayurveda.com.

[5] C.M.Jain, Anju Gupta, "Clinical study of an Ayurvedic compound Divyadi Yoga in the management of Shayyamutra (Enuresis) Ayu, 2010; 31(1): 67-75, PMC3215325.

[6] Bed wetting in children (Shayyamutra) natural remedies and tips, Brahma Ayurveda.

[7] Sachin R Bhagwat, V U Gawai, Ayurvedic management of Shayyamutra (enuresis). Aliterature review.www.ijapc.com, 2015; 240-244.

[8] KatariaAmit, Singhalharish, VinaikAshu, Neetu, Shayyamutra; A riddle in Kaumarbhritya IAMJ, 2013; 1(3): 1-5, ISSN: 23205091.

[9] Arun Raj Gr, Shende A, Shailaja U, Parikshit D, RaoPrasanna N, Clinical Study on the Efficacy of an Ayurvedic Drug in the Management of Nocturnal Enuresis in Children, Ujahm, 2013; 01(03): 55-58 